\title{
BANKRUPTCY: COUNTING PARENT AND SUBSIDIARY CORPORATIONS AS SEPARATE CREDITORS UNDER SECTION 59(b) OF THE BANKRUPTCY ACT
}

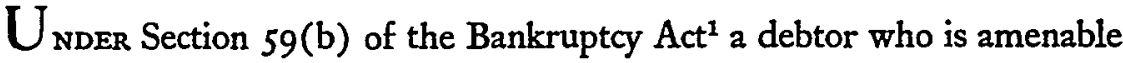
to involuntary bankruptcy ${ }^{2}$ and has twelve or more creditors with "provable claims liquidated as to amount and not contingent as to liability ... which amount in the aggregate in excess of the value of securities held by them, if any, to $\$ 500$ or over"3 may be adjudicated bankrupt upon the petition of three or more of these creditors. Whether a corporate creditor and its wholly owned and controlled subsidiary to which the parent has in good faith made a partial assignment of claims against the debtor may both qualify as petitioning creditors under the statute depends on the extent to which the entity of the subsidiary should be recognized.

In the recent case of In the Matter of Gibraltor Amusements, $L t d .{ }^{4}$ the Wurlitzer Company had received several notes of the debtor Gibraltor Amusements, a purchaser of jukeboxes from Wurlitzer. Two of these notes had been assigned to Wurlitzer Acceptance Corporation (WAC), a subsidiary corporation established for the primary purpose of financing the sales of Wurlitzer. The parent company was the sole stockholder of the subsidiary, and the two corporations had substantially the same officers and directors, including identical presidents. ${ }^{5}$ However, the corporate form was strictly followed and the corporate entity of WAC had been recognized for credit and tax purposes. Moreover, the good faith of the assignment was demonstrated by WAC's purchase of Gibraltor's notes for valid consideration long before the filing of the bankruptcy petition. ${ }^{-}$There was no evidence of a fraudu-

'Bankruptcy Act $\S 59$ (b), ch. 54I, 30 Stat. 56I (1898), as amended, II U.S.C. $\S 95$ (b) (1958) [hereinafter cited Bankruptcy Act].

"'Any natural person, except a wage earner or farmer, and any moneyed, business, or commercial corporation, except a building and loan association, a municipal, railroad, insurance, or banking corporation, owing debts to the amount of $\$ 1,000$ or over, may be adjudged an involuntary bankrupt upon default or an impartial trial and shall be subject to the provisions and entitled to the benefits of this title." Bankruptcy Act $\S 4$.

Bankruptcy Act $\$ 59$ (b).

'29r F.2d 22 (2d Cir. 1961), cert. denied, 368 U.S. 925 (1961). The facts set forth are taken from the opinion unless otherwise cited.

${ }^{5}$ Brief for Wurlitzer Company and Wurlitzer Acceptance Corporation, pp. 45a-46a, In the Matter of Gibraltor Amusements, Ltd., 291 F.2d 22 (2d Cir. 1961).

- WAC had fully complied with General Order 5(2), which requires that "Peti- 
lent attempt to subvert the Bankruptcy Act at the time of the assignment.

Gibraltor was adjudicated bankrupt by the referee after Wurlitzer filed an amended involuntary petition in bankruptcy against Gibraltor in which WAC and two individual creditors joined. On review by the bankruptcy court the adjudication was affirmed, despite the court's disqualification of one of the individual filing creditors as a petitioner. ${ }^{7}$ On appeal to the Court of Appeals for the Second Circuit, a majority of the court, pointing to the definition of "creditor" in the Bankruptcy Act as being "all encompassing," felt that neither the policy nor the language of the Bankruptcy Act made the instant case one in which the separate corporate personality of the subsidiary should be disregarded. ${ }^{8}$ While no indicia of fraud or attempted subterfuge of the Bankruptcy Act were present in the Gibraltor case, Judge Friendly contended in dissent that to recognize the separate corporate personality of WAC under the existing facts would be offensive to the policy of the Bankruptcy Act. ${ }^{9}$

The purpose of section 59(b) can be ascertained from the history of the several bankruptcy acts. ${ }^{10}$ The early acts permitted a single creditor to initiate an involuntary proceeding if the creditor's claim met the prescribed statutory minimum.11 However, because of the social

tioners in involuntary proceedings for adjudication, whose claims rest upon assignment or transfer from other persons, shall annex to one of the triplicate petitions all instruments of assignment or transfer, and an affidavit setting forth the true consideration paid for the assignment or transfer of such claims and stating that the petitioners are the bona fide holders and legal and beneficial owners thereof and whether or not they were purchased for the purpose of instituting bankruptcy proceedings." General Order $5(2)$, I I U.S.C. appendix, p. 1812 (1958).

General Order $5(2)$ was designed to avoid colorable trafficking of claims among friendly parties in order to create sufficient petitioning creditors and to advise the courta of the circumstances surrounding the transfer. Reed v. Thornton, 43 F.2d 813, 814 (9th Cir. 1930); accord, In re Kehoe, 233 Fed. 415, 417 (2d Cir. 1916). Whether the purpose for which the claim was purchased affects the status of the petitioning creditor is for the bankruptcy court to determine. See 3 Collier, Bankruptcy T 59.05, at 564 n.30 (14th ed. 1961) [hereinafter cited as CoLLIER].

'In the Matter of Gibraltor Amusements, Ltd., 187 F. Supp. 93 (

29I F.2d at 24-25.

Id. at 28 .

${ }^{10}$ Whether a subsidiary with assigned claims can qualify in the abeence of fraud as a creditor under $\S 59(\mathrm{~b})$ is not expressly answered in the Bankruptcy Act or in prior decisions. Therefore, it is necessary to look to the legislative journals to what provisions Congress would probably have made had they envisioned wuch a quention. See J. W. Ould Co. v. Davis, 246 Fed. 228 (4th Cir. IgI7); I Collres 8 I (2), at 5 (r3th ed. rg23). Annot., 70 A.L.R. 5 (1931).

11 The first national bankruptcy act, enacted in 1800 , provided for involuntary 
stigma and financial embarrassment associated with bankruptcy, it came to be felt that an insolvent debtor should not be thrown into bankruptcy unless more than one creditor wished to press his claim. ${ }^{12}$ Under an I874 amendment, therefore, one-fourth of the total number of creditors having claims totaling one-third of all provable claims against the debtor were necessary to file an involuntary bankruptcy petition. ${ }^{13}$ Neither the lax provisions of the early acts nor the stringent amendment of 1874 accomplished the Congressional desire to provide creditors with an adequate means of satisfying their claims while protecting debtors from undue harassment. ${ }^{14}$ Thus, when the Bankruptcy Act of 1898 was passed ${ }^{15}$ Congress tempered the extremities of the earlier acts by requiring three creditors to initiate an involuntary petition where the debtor has more than twelve creditors qualified to file a petition.

When there are more than twelve qualified creditors, "counting to three" is a primary concern of the courts in the application of Section 59 (b) of the Bankruptcy Act. Since the assignment or splitting of claims would provide a means of circumventing the intent of the statutory provision, ${ }^{16}$ courts have refused to include claims of a transferee

proceedings either by a single creditor with a claim of $\$ 1,000$, any two creditors with claims totaling $\$ 1,500$, or any three creditors with claims totaling $\$ 3,000$. Bankruptcy Act ch. 19, \& 2, 2 Stat. I9 (1800); see generally 2 CollieR $\$ 59$ (13th ed. I923). Dissatisfaction with the working of the act brought repeal in $x 803$. Repeal of Bankruptcy Act of I800, ch. 6, 2 Stat. 248 (I803); see I Collier 9 0.04, at 7.

The next bankruptcy act, enacted in $184 \mathrm{I}$, allowed one creditor with a claim of $\$ 500$ or more to file an involuntary bankruptcy petition. Bankruptcy Act, ch. 5,5 Stat. 440 (1841). This act was repealed in 1843. An Act to Repeal the Bankruptcy Act, ch. 82, 5 Stat. 614 (1843).

The third bankruptcy act, enacted in 1867 , allowed a claim to be filed by one or more creditors whose claims totaled an aggregate of $\$ 250$. Bankruptcy Act ch. 176, \& 39,14 Stat. $517(1867)$.

${ }_{12} 3$ Collier I 59.0I, at 548; see In re Kehoe, 233 Fed. 415 (2d Cir. I916); 31 Cong. Rec. 185 ( 1898 ) (remarks of Representative Sparkman of Florida); H.R. Rep. No. 65, 55th Cong., 2d Sess. 35 (1897); see generally 31 Cong. REc. I777-938 (1898). The Panic of 1873 resulted in a large number of business failures. The many impatiently initiated involuntary bankruptcy proceedings during that period were primarily responsible for the tide of emotion against involuntary bankruptcy. See I Hanna \& Maclachlan, Creditors' Rights 26I (4th ed. 1949).

${ }^{12}$ Bankruptcy Act $\S 39$, as amended, ch. 390, I8 Stat. 178 (1874).

${ }^{16} 3$ Collier I 59.01 , at 548 .

${ }^{15}$ Bankruptcy Act, ch. 541, 30 Stat. 544 (1898). The Bankruptcy Act of 1867 , as amended in 1874 , had been repealed in 1878 . An Act to Repeal the Bankrupt Law, ch. 160 , 20 Stat. 99 (1878). See 3 CollieR 59.01 , at 548.

${ }^{16}$ See Emerine v. Tarault, 219 Fed. 68 (6th Cir. 1915); Stroheim v, Lewis F. Perry \& Whitney Co., I75 Fed. 52 (Ist Cir Igro); Leighton v. Kennedy, 129 Fed. 737 (1st Cir. 1904); In re Burlington Malting Co., rog Fed. 777 (E.D. Wis. I90i); In re Woodford, 30 Fed. Cas. 492 (No. 17,972) (N.D. Ohio 1876 ). 
if the assignment was made solely to create additional creditors. ${ }^{17}$ Otherwise, one creditor could transfer portions of his claim to assignees willing to join in bankruptcy proceedings, thereby causing one claim to be counted several times. ${ }^{18}$

Though courts are reluctant to disregard the separate legal entity of a corporation, ${ }^{10}$ it is submitted that the historical development of section 59 (b) requires the denial of separate creditor status to a subsidiary corporation on the facts present in the Gibraltor case. While unity of ownership and management are usually not in themselves sufficient grounds for denying recognition of separate corporate personalities, ${ }^{20}$ it would seem that, as Judge Friendly pointed out, the purpose of section 59 (b) is to prevent a debtor with twelve or more creditors from being adjudicated bankrupt on less than three distinct decisions. ${ }^{21}$ When a decision to file an involuntary petition of bank-

${ }^{27}$ See In re Tribelhorn, 137 Fed. 3 (2d Cir. 1905); In re H.E. Page Motor Car Co., 251 Fed. 318 (D.C. Mass. 1918); 3 Collier I 59.05, at 558; cf. In te Glory Bottling Co., 278 Fed. 625 (E.D.N.Y. 192x), rew'd on other grounds 283 Fed. 110 (2d Cir. 1922) (mere fact claim based on trade acceptance did not invalidate involuntary petition). But see In re Bevins, 165 Fed. 434 (2d Cir. 1908) (claims purchased for nominal amount with specific purpose of making up required statutory number held valid). Even the majority of the court in the instant case felt that the decision in Bevins was "overly liberal." 291 F.2d at 25 .

${ }^{18} \mathrm{~A}$ creditor should not obtain a benefit that Congress sought to deny him. In re Independent Thread $\mathrm{Co}_{0},{ }_{113}$ Fed. 998 (D.C.N.J. 1902); accord, In re Tribelhorn, supra note $x 7$; In re Halsey Electric Generator Co., 163 Fed. 1 1 8 (D.C.N.J. 1908), appeal dismissed sub nom. Hogg v. Halsey Electric Generator Co., 169 Fed. 1021 (3d Cir. 1909).

${ }^{10}$ See, e.g., Rapid Transit Subway Constr. Co. v. City of New York, 259 N.Y. 472, 882 N.E. 145 (1932); Oceanic Insul-Lite Corp. v. Sullivan Dry Dock \& Repair Corp., 191 Misc. 354, 77 N.Y.S.2d 498 (1947).

The "corporate veil" is pierced most often when the facts demonstrate that the corporation is merely the alter ego or business conduit of its governing or dominating personality. See generally LaTTY, SUBSIDIARIES AND AFFILIATED CORPORaTIONS $\S 47$ (1936). The corporate entity is also not recognized where the equities will not warrant recognition, or where recognition will defeat public convenience. United States v. Milwaukee Refrigerator Transit Co., 142 Fed. 247 (C.C.E.D. Wis. 1905); accord, Shamrock Oil \& Gas Co. v. Ethridge, 159 F. Supp. 693 (D. Colo. 1958). See generally $x$ O'Neal, Close Corporations $\$ 1.09$, at 21 (1958).

${ }^{20}$ I Fletcher, Cyclopedia of Corporations $§ 43$, at 157 (rev. perm. ed. $x 931$ ).

${ }^{21} 29 x$ F.2d at 28 . Judge Friendly also noted that although there was no fraudulent purpose to subvert the Bankruptcy Act when the claims were placed with WAC, the parent might have been attempting to insure its ability to initiate involuntary bankruptcy "by the simple expedient of organizing two financing subsidiaries . . . and seeing to it that claims against each debtor are parceled out in advance of bankruptcy." Ibid. Bankruptcy may, however, have been the furthest thing from the mind of Wurlitzer when the claims were placed. Id. at n.6. 
ruptcy is made for two or more corporations by a single individual or managerial unit, in reality there is but one decision. Because the corporate entity should not be used as a device to defeat legislative policy, ${ }^{22}$ that decision should be counted only once.

One of the stronger arguments for the Second Circuit's recognition of WAC's claim as a separate creditor is the absence of an express statutory provision specifying when the corporate entity should be disregarded under section 59(b), ${ }^{23}$ especially in light of section 59 (e)'s exclusion of certain classes of creditors for purposes of "counting to three..24 It might be contended that the enumeration of these specific exclusions serves to negate the disqualification of other creditors. However, the purpose of section $59(\mathrm{e})$ is to exclude those creditors who would be prone to oppose an involuntary petition because of a consanguineous or friendly relationship with or domination by the debtor. That section does not purport to concern itself with creditors who should be excluded because of intra-creditor relationships such as that existing between a corporation and its subsidiary.

In the absence of a provision pertaining to the exclusion of related corporate entities, it would seem proper to seek guidance from the history of past and present bankruptcy legislation. That history proves that the purpose of section 59 (b) is to require three distinct decisions as to whether an involuntary petition should be filed. No other inference can be extracted from the whole of the Bankruptcy Act.

\footnotetext{
${ }^{23}$ See Henn, Corporations § 151, at 214 (1961).

3s The majority pointed out that while "Congress has repeatedly added to and amended the Federal taxing law to deal with the problems [of] ... multiple corporation[s] . . . it has not seen fit similarly to tinker with the Bankruptcy Act." $29 \mathrm{I}$ F.2d at 25 .

Comstock v. Group of Investors, 335 U.S. 211 (1948), relied on by the court, 29 I F.2d at 25 , allowed a parent corporation to recover from its subsidiary in corporate reorganization proceedings, thereby recognizing the separate personality of both corporations. However, Comstock arose in a completely different context from the instant case. The relationship between the companies was that of debtor-creditor; it was not an intra-creditor relationship as was present in the Gibraltor case.

34 Those creditors that shall not be counted are "( $\mathrm{x}$ ) such creditors as were employed by the bankrupt at the time of the filing of the petition; (2) creditors who are relatives of the bankrupt or, if the bankrupt is a corporation, creditors who are stockholders or members, officers or members of the board of directors or trustees or other similar controlling bodies of such bankrupt corporation; (3) creditors who have participated, directly or indirectly, in the act of bankruptcy charged in the petition; (4) secured creditors whose claims are fully secured; and (5) creditors who have received preferences, liens, or transfers void or voidable under the title." Bankruptcy Act $\S 59(\mathrm{e})$.
} 